Научная статья

Удк 379.844

DOI https://doi.org/10.24866/VVSU/2073-3984/2021-4/037-049

\title{
В.И. Суржиков
}

Владивостокский государственный университет экономики и сервиса Владивосток. Россия

\section{Организация событийных мероприятий в границах туристско-рекреационных пространств города}

\begin{abstract}
Аннотация. Событийная активность в границах открытых общественных туристскорекреационных пространств призвана не только интенсифицировать развитие активных форм рекреации населения крупного города в природной среде, но и формировать его привлекательный туристский имидж. Цель научной работы состоит в определении современного уровня и потенциальных возможностей организации событийной активности в границах открытых туристско-рекреационных пространств Ленинского района города Владивостока. Методическую основу работы составила авторская оценка событийной активности с использованием методов сравнительного анализа, социологического, статистического, балльной оценки. Основное внимание уделяется разработке методики оценки событийной активности, проводится отбор двадцати восьми показателей, объединённых в восемь блоков: функциональные характеристики пространств, транспортная доступность, санитарно-гигиенические стандарты, безопасность отдыха, наличие достопримечательностей и иных отличительных объектов, инфраструктура, объекты общественного питания, наличие специально оборудованных мест для мероприятий. Собраны данные по выбранным критериям и проведена оценка двадцати одного туристско-рекреационного пространства Ленинского района города Владивостока. Полученные результаты свидетельствуют о низком уровне потенциальных возможностей организации событийной активности в их границах и крайней необходимости их реновации. Практическая значимость состоит в определении возможных вариантов их модернизации.
\end{abstract}

Ключевые слова: открытые туристско-рекреационные пространства, событийные мероприятия, балльная оценка, социологический опрос, туристская дестинация.

\section{V.I. Surzhikov}

Vladivostok State University of Economics and Service

Vladivostok. Russia

Суржиков Виктор Иванович - ст. преподаватель Международного института туризма и гостеприимства. ORCID: https://orcid.org/0000-0001-8846-9521; e-mail: Viktor.Surzhikov@vvsu.ru 


\title{
Organization of events within the boundaries of tourist and recreational spaces of the city
}

\begin{abstract}
Event activity within the boundaries of open public tourist and recreational spaces is designed not only to intensify the development of active forms of recreation for the population of a large city in the natural environment, but also to form its attractive tourist image. The purpose of the scientific work is to determine the current level and potential opportunities for organizing event activity within the open tourist and recreational spaces of the Leninsky district of the city of Vladivostok. The methodological basis of the work was the author's assessment of event activity using the methods of comparative analysis, sociological, statistical, point assessment. The work focuses on the development of a methodology for assessing event activity, twenty-eight indicators are selected, combined into eight blocks: functional characteristics of spaces, transport accessibility, sanitary and hygienic standards, safety of recreation, the presence of attractions and other distinctive objects, infrastructure, catering facilities, availability of specially equipped places for events. Collected data on the selected criteria and conducted an assessment of twenty-one tourist and recreational space of the Leninsky district of the city of Vladivostok. The results obtained indicate a low level of potential opportunities for organizing event activity within their boundaries and an urgent need for renovation. The practical significance lies in identifying possible options for their modernization.
\end{abstract}

Keywords: public open tourist and recreational spaces, events, point assessment, sociological survey, tourist destination.

\section{Введение}

За последние десять лет наблюдается активный рост интереса к общественным пространствам городов, в особенности к открытым туристско-рекреационным. Это обусловлено, с одной стороны, высоким уровнем урбанизации населения, широким использованием его умственного труда, заменой активных форм рекреации в природной среде на пассивные в помещениях. С другой стороны, туристско-рекреационные пространства являются неотъемлемой частью любой туристской дестинации, выполняют функцию притяжения туристов и формируют имидж территории.

Анализ зарубежного опыта свидетельствует о том, что существует много успешных практик организации событийных мероприятий в их границах. К примеру, всемирно известные «Сады у залива» в городе-государстве Сингапуре в 2019 г. посетило более 20 млн туристов. На площади 101 га ежегодно проводится международный цветочный фестиваль.

В парке «Bayfront Park» в г. Майами (США) проходят крупные событийные мероприятия, в том числе новогодние и рождественские праздники и концерты. Для их организации в парке есть открытый амфитеатр на 10000 мест, павильон на 1000 мест, точки питания и туалетные зоны. Здесь проходит фестиваль электронной музыки «Ультра», который продолжается неделю и собирает до 60000 посетителей ежедневно.

На острове Обуда в г. Будапеште (Венгрия) проводится музыкальный фестиваль «Sziget Fest». Возможности данного пространства позволяют организо- 
вывать различные городские события: забеги, киновечера и др. Пространство многофункционально.

«Red Rocks Amphitheatre» в г. Моррисон (США) используется для проведения разного уровня фестивалей. Естественный амфитеатр располагает идеальной акустикой для создания уникальных событий и привлечения туристского потока.

Приведённые примеры открытых туристско-рекреационных пространств представляют собой уникальные природные площадки, которые используются для проведения событийных мероприятий и привлечения туристов.

Актуальность рассматриваемой проблемы, ее практическая значимость определили выбор темы данной статьи и послужили основой для формулирования ее цели и задач.

Цель работы - дать оценку современному уровню и потенциальным возможностям организации событийной активности в границах открытых туристско-рекреационных пространств Ленинского района города Владивостока. Достижение поставленной цели потребовало решить ряд задач:

- проанализировать современное состояние организации событийных мероприятий;

- провести анкетирование местных жителей и туристов для формирования представления о современном состоянии и возможностях организации событийной активности;

- провести отбор критериев и сбор данных по выбранным критериям.

Предмет исследования, источниковая база исследования, противоречия в имеющихся исследованиях и авторская позиция

Предметом исследования работы являются открытые общественные туристско-рекреационные пространства г. Владивостока на примере Ленинского района.

Анализ публикаций по теме исследования показал, что работы отечественных авторов чаще всего посвящены вопросам изучения рекреационного пространства в структуре города $[1,2]$, типологии туристско-рекреационного пространства [3], формированию [4, 5], конструированию [6] и креативизации [7] рекреационного пространства крупного российского города, современным тенденциям многоуровневой организации рекреационных пространств в городской среде [8], теоретикометодологическим основам комплексного экономико-географического анализа туристского пространства [9] и развитию современного городского пространства в туристических целях [10], оценке уровня комфортности туристско-рекреационных пространств города [11], специфике рекреационного пространства отдельных городов [12-14], рекреационному пространству как объекту управления инновационным развитием территории города [15].

Несмотря на обилие публикаций, вопрос организации событийной активности туристско-рекреационных пространств города остаётся не изученным в отечественной литературе.

Методы исследования: сравнительный анализ, социологический и статистический методы, метод балльной оценки. 


\section{Основная часть}

Для оценки современного уровня и потенциальных возможностей организации событийной активности в границах туристско-рекреационных пространств города автором был взят Ленинский район г. Владивостока. В районе идентифицировано 21 открытое туристско-рекреационное пространство: 2 набережные, 1 городская площадь, 2 парка, 16 скверов.

Каждое пространство было оценено с точки зрения современного уровня событийной активности. Проведён отбор и структуризация данных на основе афиши и событийного календаря г. Владивостока. Результаты приведены на рис. 1.

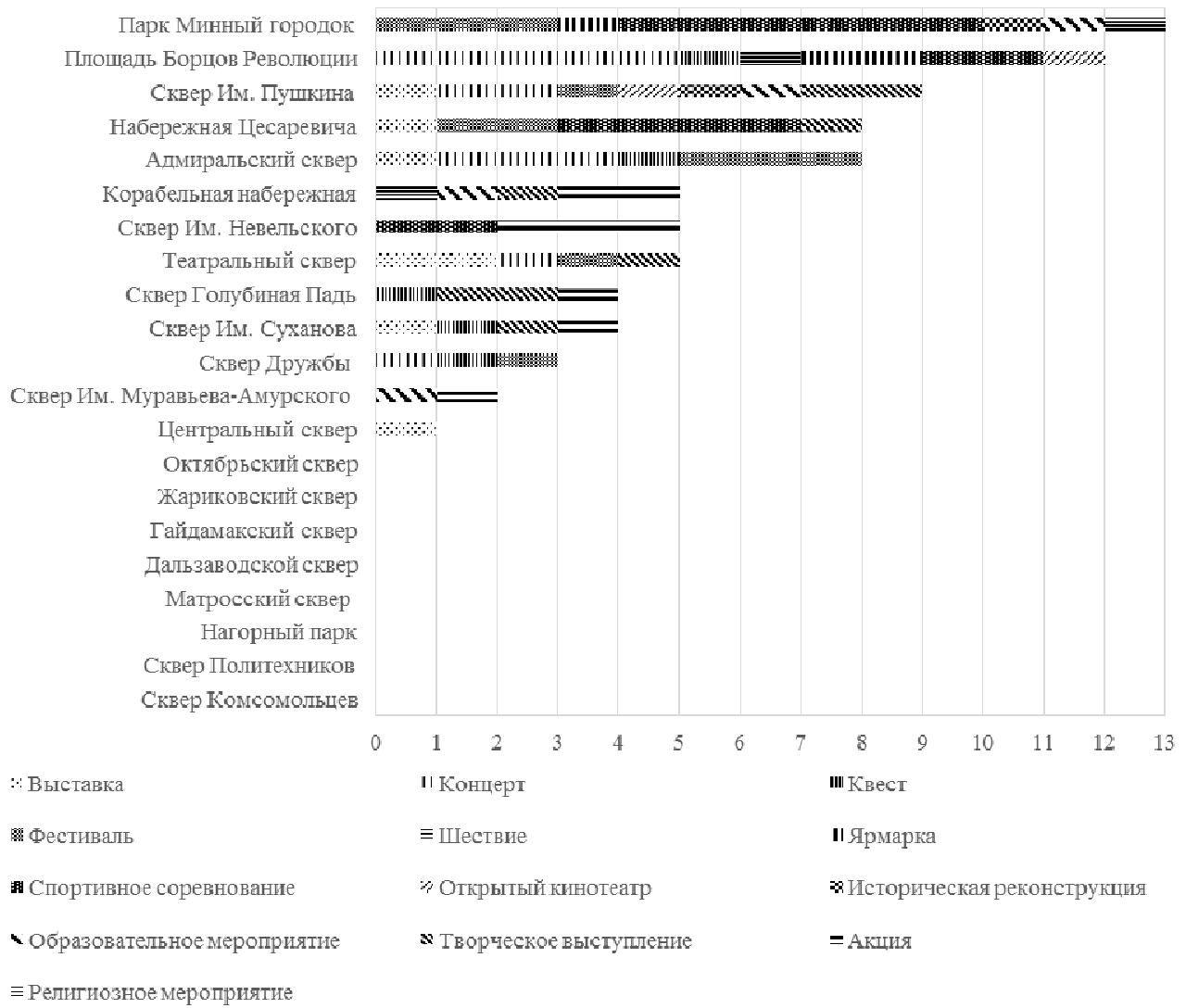

Рис. 1. Количество и типы событийных мероприятий, ежегодно проводимых в границах туристско-рекреационных пространств Ленинского района г. Владивостока

Только в 13 из 21 пространства проводятся событийные мероприятия. Максимальное значение принадлежит парку Минный городок и площади Борцов Революции, минимальное - Центральному скверу. Всего насчитывается 13 типов мероприятий. Чаще всего проводятся спортивные мероприятия, концерты и фестивали, наименее распространены - религиозные мероприятия, исторические реконструкции, открытый кинотеатр и шествия. 
Далее был проведён социологический опрос местных жителей и гостей города с целью выявить их мнение об организации событийных мероприятий в границах туристско-рекреационных пространств. Анкета была создана с использованием Google Forms; включала в себя 10 вопросов. В опросе приняло участие 166 респондентов, из которых женщин - 134, мужчин - 32.

В возрасте до 18 лет насчитывалось $1,8 \%$ респондентов, от 18 до 25 лет $84,3 \%$, от 26 до 30 лет - 13,3\%, от 46 до 55 лет - 0,6\%. Распределение по роду занятий позволило выяснить, что $56,7 \%$ респондентов являются студентами, $38,1 \%$ - работают, $4 \%$ - безработные, $0,6 \%$ - индивидуальные предприниматели, $0,6 \%$ опрошенных находятся в декретном отпуске.

На вопрос о частоте посещаемости открытых туристско-рекреационных пространств $59 \%$ опрошенных ответили, что посещают их несколько раз в неделю, $22,3 \%$ - раз в неделю, 18,1\% - ежемесячно, $6 \%$ - каждый день, $1,2 \%$ - 1 раз в год и реже, 0,6\% - 1 раз в несколько месяцев. Приведенные результаты подтверждают востребованность среди населения открытых рекреационных пространств и их частую посещаемость (рис. 2).

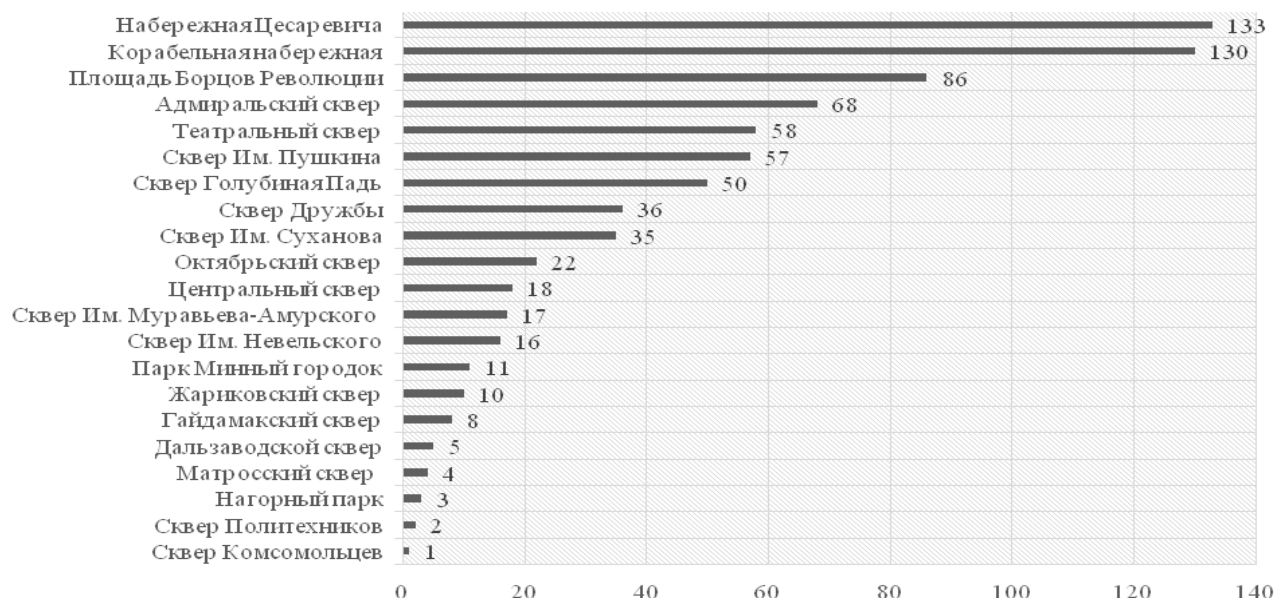

Рис. 2. Наиболее часто посещаемые открытые рекреационные пространства Ленинского района г. Владивостока, чел.

Среди лидеров по посещаемости оказались набережные Цесаревича и Корабельная, площадь Борцов Революции и Адмиральский сквер, наименее посещаемыми - Жариковский, Гайдамакский, Дальзаводской, Матросский, Политехников, Комсомольцев скверы и Нагорный парк.

На вопрос о цели посещения открытых туристско-рекреационных пространств 83,7 \% респондентов отметили прогулку в свободное время, $45 \%$ проведение досуга (пикник, прогулка на самокатах), $15 \%$ - занятия спортом и всего $25,9 \%$ - посещение событийного мероприятия.

Респондентам предлагалось выбрать из перечня возможных проблем открытых туристско-рекреационных пространств наиболее часто встречающиеся. 
Опрос выявил, что проблема мусора на территории беспокоит $61 \%$ опрошенных, отсутствие урн - 51,2\%, инфраструктуры для событийных мероприятий и недостаточное количество зон питания - по $48 \%$, отсутствие скамеек, плохое состояние пешеходных дорожек - по 46,3\%, отсутствие информационных стендов $-34,1 \%$ и организованного входа $-17 \% .163$ человека ответили, что стали бы посещать туристско-рекреационные пространства чаще при условии устранения всех вышеперечисленных проблем.

Далее у горожан были выявлены предпочтения в событийных мероприятиях, которые могли бы проводиться в границах открытых туристскорекреационных пространств (рис. 3).

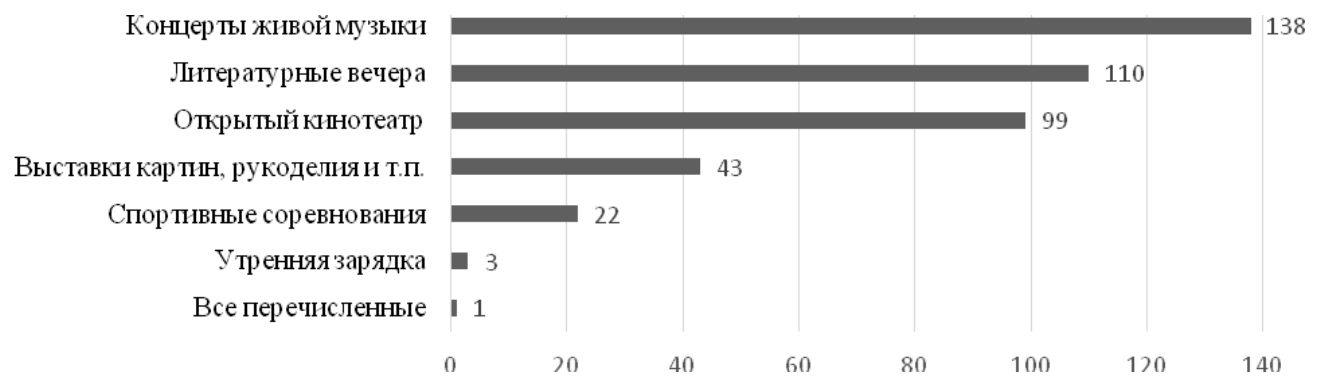

Рис. 3. Предпочтения горожан в событийных мероприятиях, чел.

Абсолютное большинство респондентов отметили необходимость проведения концертов живой музыки, литературных вечеров и открытых кинотеатров. $64 \%$ опрошенных также высказались за необходимость организации мест для открытого лектория / площадки для мастер-классов и $64 \%$ - за организацию площадки для выступлений творческих коллективов.

Одновременно с опросом горожан проводилось социологическое исследование туристов г. Владивостока. Оно состояло из девяти вопросов. Пять из предложенных вопросов анкеты касались непосредственно посещения, состояния и наличия проблем туристско-рекреационных пространств и 3 вопроса личным данным респондентов. В опросе приняло участие 54 респондента, из которых женщин - 29, мужчин - 25 .

14 туристов прибыли из Хабаровского края (г. Хабаровск), 14 из Амурской области (г. Свободный, г. Благовещенск, г. Белогорск), 13 из Приморского края (г. Находка, пгт. Лучегорск, г. Уссурийск), 6 из Камчатского края, 4 из г. СанктПетербурга, а также по 1 человеку из Красноярского края (г. Канск), Республики Татарстан (г. Казань), г. Москвы.

Наибольшее количество опрошенных туристов чаще всего посещали набережные, площадь Борцов Революции и парки (рис. 4). 
В.И. Суржиков. Организация событийных мероприятий...

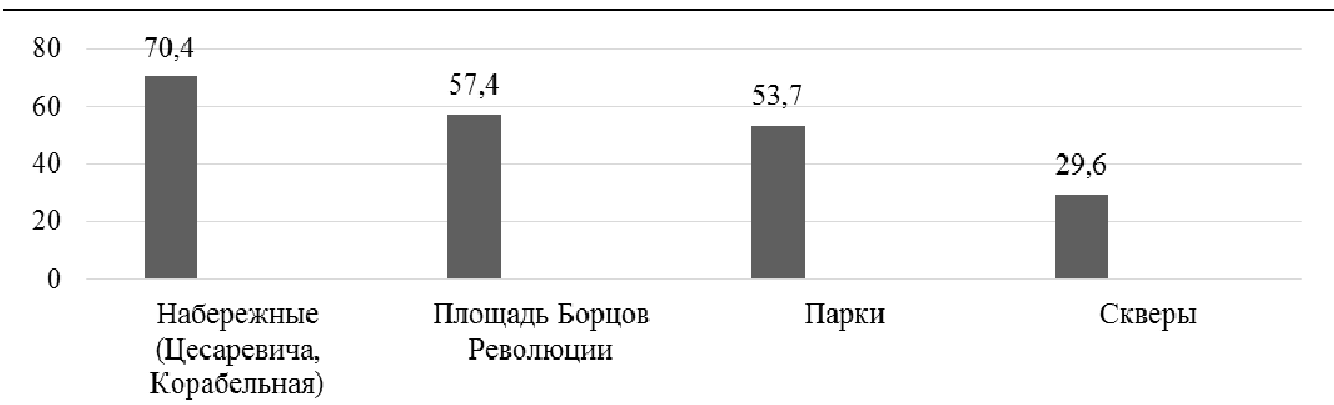

Рис. 4. Посещаемость туристами открытых туристско-рекреационных пространств Ленинского района г. Владивостока, \%

$61 \%$ опрошенных отметили, что удовлетворены состоянием посещаемых пространств, но в них присутствуют недостатки: отсутствие урн - 33 чел., отсутствие инфраструктуры для событийных мероприятий - 30 чел., отсутствие скамеек - 26 чел., отсутствие организованной входной группы и информационных стендов - 24 чел., плохое состояние пешеходных дорожек и отсутствие туалетов - 14 чел., замусоренность территории - 10 чел.

При этом всего $3 \%$ опрошенных ответили, что присутствовали на событийных мероприятиях двух типов (ярмарка и фестиваль), проводимых в границах общественных пространств.

Далее была проведена авторская оценка открытых туристскорекреационных пространств с точки зрения возможности организации событийных мероприятий. Выделены 28 показателей, объединённых в 8 блоков: функциональные характеристики пространств, транспортная доступность, санитарно-гигиенические стандарты, безопасность отдыха, наличие достопримечательностей и иных отличительных объектов, инфраструктура, объекты общественного питания, наличие специально оборудованных мест для мероприятий (табл. 1).

Таблий 1

Критерии оценки возможности организации событийных мероприятий в границах туристско-рекреационного пространства

\begin{tabular}{|c|c|}
\hline Блок & Показатель \\
\hline \multirow{4}{*}{$\begin{array}{l}\text { 1. Функциональные характе- } \\
\text { ристики пространств }\end{array}$} & 1.1. Площадь \\
\hline & 1.2. Конфигурация (прямоугольное, линейное и пр.) \\
\hline & 1.3. Перепады высот на территории \\
\hline & 1.4. Процент залесённости территории \\
\hline \multirow{2}{*}{ 2. Транспортная доступность } & $\begin{array}{l}\text { 2.1. Расстояние от основного входа до ближайших остановок } \\
\text { общественного транспорта пешком }\end{array}$ \\
\hline & 2.2. Наличие парковки (авто-, вело-) \\
\hline
\end{tabular}


Территория новых возможностей. Вестник ВГУЭС. 2021. № 4

Окончание табл. 1

\begin{tabular}{|c|c|}
\hline Блок & Показатель \\
\hline \multirow[b]{2}{*}{$\begin{array}{l}\text { 3. Санитарно-гигиенические } \\
\text { стандарты }\end{array}$} & 3.1. Наличие мусора в местах, не оборудованных для сбора \\
\hline & $\begin{array}{l}\text { 3.2. Наличие необходимого количества урн на территории, т.е. } \\
\text { не реже чем через каждые } 40 \text { м (согласно СанПиН 2.1.7.3550- } \\
\text { 19) [16] }\end{array}$ \\
\hline \multirow{4}{*}{$\begin{array}{l}\text { 4. Безопасность } \\
\text { отдыха }\end{array}$} & 4.1. Расстояние до ближайшего пункта полиции \\
\hline & $\begin{array}{l}\text { 4.2. Наличие медицинского пункта в радиусе } 1000 \text { м (согласно } \\
\text { СП 42.13330.2016) [17] }\end{array}$ \\
\hline & 4.3. Отсутствие бездомных и иных маргинальных групп \\
\hline & 4.4. Отсутствие бродячих животных \\
\hline \multirow{2}{*}{$\begin{array}{l}\text { 5. Наличие достопримеча- } \\
\text { тельнос- тей и иных отличи- } \\
\text { тельных объектов }\end{array}$} & $\begin{array}{l}\text { 5.1. Мемориальные сооружения, религиозные объекты, } \\
\text { скульптуры, памятники и прочие достопримечательности; не } \\
\text { занимают более } 50 \text { \% площади }\end{array}$ \\
\hline & $\begin{array}{l}\text { 5.2. Объекты различной ландшафтной архитектуры (водоёмы, } \\
\text { аллеи, рощи и пр.) }\end{array}$ \\
\hline \multirow{5}{*}{ 6. Инфраструктура } & 6.1. Количество входов \\
\hline & $\begin{array}{l}\text { 6.2. Наличие общественных туалетов (не ближе } 50 \text { м от массо- } \\
\text { вого скопления людей, } 1 \text { туалет на } 500 \text { человек (согласно } \\
\text { СанПиН 2.1.7.3550-19) [16] }\end{array}$ \\
\hline & $\begin{array}{l}\text { 6.3. Наличие плана-схемы, указателей и информационных } \\
\text { стендов }\end{array}$ \\
\hline & 6.4. Наличие электрификации \\
\hline & 6.5. Наличие необходимого количества скамеек \\
\hline \multirow{2}{*}{$\begin{array}{l}\text { 7. Объекты общественного } \\
\text { питания }\end{array}$} & 7.1. Пункты продажи воды \\
\hline & 7.2. Пункты быстрого питания \\
\hline \multirow{7}{*}{$\begin{array}{l}\text { 8. Наличие специально обо- } \\
\text { рудованных мест для меро- } \\
\text { приятий }\end{array}$} & 8.1. Спортивные площадки \\
\hline & 8.2. Газоны для пикников \\
\hline & 8.3. Места для настольных игр \\
\hline & 8.4. Места для тихого отдыха \\
\hline & 8.5. Места для посетителей лекториев и концертов \\
\hline & 8.6. Укрытия на случай неблагоприятных погодных условий \\
\hline & 8.7. Площадка / сцена для проведения концертов, событий \\
\hline
\end{tabular}

По результатам оценки наивысший балл из 28 максимально возможных получили площадь Борцов Революции (22), набережные Цесаревича (21) и Корабельная (20), а также сквер им. А.С. Пушкина (19); наименьший (12) - скверы 
Октябрьский, Дальзаводской, Матросский, Политехников, Гайдамакский и Комсомольцев.

Полученные результаты свидетельствуют о низком уровне потенциальных возможностей организации событийной активности в границах открытых общественных пространств Ленинского района г. Владивостока и крайней необходимости их реновации. Для общественных пространств, получивших наименьший балл, предложены варианты их модернизации (табл. 2).

Таблица 2

\section{Варианты модернизации некоторых открытых общественных туристско-рекреационных пространств Ленинского района г. Владивостока}

\begin{tabular}{|c|c|c|}
\hline $\begin{array}{l}\text { Рекреационное } \\
\text { пространство }\end{array}$ & Создание элементов для событий & Тип события \\
\hline \multirow{2}{*}{$\begin{array}{l}\text { Сквер } \\
\text { Комсомольцев }\end{array}$} & $\begin{array}{l}\text { Выставочная зона летнего функ- } \\
\text { ционирования рядом с памятни- } \\
\text { ком В.Б. Баневуру }\end{array}$ & $\begin{array}{l}\text { Выставка-продажа изделий творче- } \\
\text { ства; } \\
\text { военно-патриотические выставки для } \\
\text { ветеранов Великой Отечественной } \\
\text { войны в «День Победы» }\end{array}$ \\
\hline & Многофункциональная площадка & $\begin{array}{l}\text { Лекторий от молодежных организа- } \\
\text { ций («Молодежь Приморья»); } \\
\text { музыкальные и танцевальные вечера } \\
\text { в рамках городских событий }\end{array}$ \\
\hline \multirow{2}{*}{$\begin{array}{l}\text { Октябрьский } \\
\text { сквер }\end{array}$} & $\begin{array}{l}\text { Многофункциональная площадка } \\
\text { для выступлений, иллюминация } \\
\text { на площадке }\end{array}$ & $\begin{array}{l}\text { Танцевальные вечера; } \\
\text { фестиваль уличных музыкантов и } \\
\text { театральных постановок }\end{array}$ \\
\hline & $\begin{array}{l}\text { Выставочная зона летнего функ- } \\
\text { ционирования рядом с памятником } \\
\text { корейскому политику Ли Дон Хви }\end{array}$ & $\begin{array}{l}\text { Выставка музейных экспозиций; } \\
\text { временная картинная галерея }\end{array}$ \\
\hline \multirow{3}{*}{$\begin{array}{l}\text { Матросский } \\
\text { сквер }\end{array}$} & $\begin{array}{l}\text { Создание амфитеатра на } \\
\text { территории сквера перед зданием } \\
\text { Матросского клуба }\end{array}$ & $\begin{array}{l}\text { Литературные вечера; } \\
\text { открытые лектории; } \\
\text { фестиваль уличных музыкантов и } \\
\text { театральных постановок }\end{array}$ \\
\hline & $\begin{array}{l}\text { Создание спортивной площадки в } \\
\text { формате мини-веревочного лаби- } \\
\text { ринта }\end{array}$ & $\begin{array}{l}\text { Детские турниры, спортивное ориен- } \\
\text { тирование }\end{array}$ \\
\hline & $\begin{array}{l}\text { Выставочная зона летнего } \\
\text { функционирования }\end{array}$ & $\begin{array}{l}\text { Военно-патриотические интерактив- } \\
\text { ные выставки для ветеранов Великой } \\
\text { Отечественной войны }\end{array}$ \\
\hline $\begin{array}{l}\text { Гайдамакский } \\
\text { сквер }\end{array}$ & $\begin{array}{l}\text { Многофункциональная площадка, } \\
\text { вечерняя иллюминация на пло- } \\
\text { щадке }\end{array}$ & $\begin{array}{l}\text { Ностальгические вечера для } \\
\text { людей преклонного возраста; } \\
\text { концерты живой музыки; } \\
\text { лекторий и мастер-классы от моло- } \\
\text { дежных объединений города }\end{array}$ \\
\hline
\end{tabular}


Окончание табл. 2

\begin{tabular}{|l|l|l|}
\hline $\begin{array}{c}\text { Рекреационное } \\
\text { пространство }\end{array}$ & \multicolumn{1}{|c|}{ Создание элементов для событий } & \multicolumn{1}{|c|}{ Тип события } \\
\hline & $\begin{array}{l}\text { Выставочная зона рядом с обели- } \\
\text { ском Братской могилы моряков } \\
\text { Тихоокеанского флота }\end{array}$ & $\begin{array}{l}\text { Военно-патриотические выставки, } \\
\text { посвящённые Великой Отечествен- } \\
\text { ной войне и другим событиям; } \\
\text { фотовыставки; } \\
\text { выставки-продажи декоративно- } \\
\text { прикладного творчества }\end{array}$ \\
\hline
\end{tabular}

Кроме предложенных типов событий существует целый ряд других: детский фестиваль, уроки изобразительного искусства, чемпионаты по настольным играм (домино, шашки, шахматы), кинопоказ, йога, фитнес и др.

\section{Выводы и научная новизна}

В ходе исследования поставлены и выполнены следующие задачи:

- проведён анализ современного состояния организации событийных мероприятий в границах 21 туристско-рекреационного пространства Ленинского района г. Владивостока;

- составлены анкеты для местных жителей и туристов, проведено анкетирование;

- отобраны 28 критериев, осуществлен сбор данных по ним;

- дана оценка потенциальной возможности организации событийных мероприятий в границах каждого из 21 туристско-рекреационного пространства;

- предложены варианты модернизации некоторых открытых общественных пространств.

Научная новизна исследования заключается в предложенной авторами методике оценки потенциальной возможности организации событийной активности открытых общественных туристско-рекреационных пространств, которая может быть использована органами государственной власти для улучшения условий краткосрочной рекреации местных жителей, а также для формирования привлекательного туристского имиджа города Владивостока.

1. Беспалова А.А. Рекреационное пространство крупного российского города: креативные практики конструирования: дис. ... канд. социол. наук: 22.00.04. - Ростов-наДону, 2016. - $171 \mathrm{c.}$

2. Карпова К.А., Грин И. Ю. Рекреационные пространства в структуре города // Дальний Восток: Проблемы развития архитектурно-строительного комплекса. - Хабаровск: Тихоокеанский государственный университет, 2016. - Вып. 1. - С. 477.

3. Конышев Е. В. Типология туристско-рекреационного пространства // Географический вестник. - Пермь: Пермский государственный национальный исследовательский университет, 2020. - Вып. 1(52). - С. 32. 
4. Трунина М. Ю., Билык А. Г., Чумакова И. М. Формирование рекреационного пространства города: теоретический аспект // Туризм и гостеприимство. - Пинск: Полесский государственный университет, 2020. - Вып. 1. - С. 46.

5. Матюгина Э. Г. К вопросу формирования рекреационного пространства города // Экономика и предпринимательство. - Москва, 2014. - Вып. 4. - С. 201.

6. Беспалова А. А. Ключевые акторы конструирования рекреационного пространства крупного российского города: потенциал креативности // Гуманитарий юга России. Ростов-на-Дону: Федеральный научно-исследовательский социологический центр РАН, Южный федеральный университет, 2016. - Вып. 5. - С. 189.

7. Беспалова А. А. Культурно-исторические факторы креативизации рекреационного пространства крупного российского города // Гуманитарные социальноэкономические и общественные науки. - Краснодар: Наука и образование, 2017. Вып. 10. - С. 17.

8. Баклаженко Е. В. Современные тенденции многоуровневой организации рекреационных пространств в городской среде // Развитие и актуальные вопросы современной науки. - Магнитогорск: ИП Вахрушев В.И., 2017. - Вып. 7. - С. 172.

9. Мечковская О. А. Теоретико-методологические основы комплексного экономикогеографического анализа туристского пространства // Социально-экономическая география: история, теория, методы: сборник научных статей. - Смоленск: Универсум, 2011. $-608 \mathrm{c}$.

10. Вишневская Е. В. Развитие современного городского пространства в туристических целях // Стратегические изменения в сфере туризма и гостеприимства: поиск нового вектора развития: материалы Всероссийской научно-практической конференции. Москва: Издательство Русайнс, 2018. - С. 107.

11. Суржиков В. И., Суркова А. С. Оценка уровня комфортности туристско-рекреационных пространств города // Территория новых возможностей. Вестник Владивостокского государственного университета экономики и сервиса. - Владивосток: Издательство ВГУЭС, 2020. - Т. 12, вып. 1. - С. 50.

12. Морозова В. В. Специфика рекреационного пространства малого исторического города на примере Ростова Ярославского // Ярославский педагогический вестник. Ярославль: Ярославский государственный педагогический университет им. К.Д. Ушинского, 2010. - Вып. 4. - С. 177.

13. Слюнченко Р.А. Специфика рекреационного пространства города Брянска // Вестник Брянского университета. - Брянск: Брянский государственный университет имени академика И.Г. Петровского, 2014. - Вып. 4. - С. 183.

14. Филанова Т.В. Исследование городских общественных и рекреационных пространств Самары // Традиции и инновации в строительстве и архитектуре. Архитектура и дизайн. - Самара: Самарский государственный архитектурно-строительный институт, 2015. - С. 234.

15. Десятниченко Д. Ю., Запорожан А. Я., Куклина Е. А. Рекреационное пространство как объект управления инновационным развитием территорий города // Управленческое консультирование. - Санкт-Петербург: Российская академия народного хозяйства и государственной службы при Президенте РФ, 2017. - Вып. 9. - С. 64.

16. СанПиН 2.1.7.3550-19. Санитарно-эпидемиологические требования к содержанию территорий муниципальных образований: утв. Постановлением главного гос. санитарного врача Российской Федерации от 05.12.2019 № 20. Введены с 26.12.2019 // Электронный фонд правовых и нормативно-технических документов. - URL: https://docs.cntd.ru/document/564067935?marker=6560IO (дата обращения: 18.07.2021). 
17. Свод правил СП 42.13330.2016. «Градостроительство. Планировка и застройка городских и сельских поселений». Актуализированная редакция СНиП 2.07.01-89: утв. Приказом Министерства строительства и жилищно-коммунального хозяйства Российской Федерации от 30 декабря 2016 г. № 1034/пр. Дата введения 01.07.2017 // Электронный фонд правовых и нормативно-технических документов. - URL: https://docs.cntd.ru/document/456054209 (дата обращения: 20.07.2021).

\section{Транслитерация}

1. Bespalova A. A. Rekreacionnoe prostranstvo krupnogo rossijskogo goroda: kreativ-nye praktiki konstruirovaniya: dis. ... kand. sociol. nauk: 22.00.04. - Rostov-na-Donu, 2016. $171 \mathrm{~s}$.

2. Karpova K. A., Grin I. Yu. Rekreacionnye prostranstva v strukture goroda // Dal'-nij Vostok: Problemy razvitiya arhitekturno-stroitel'nogo kompleksa. - Habarovsk: Tihookeanskij gosudarstvennyj universitet, 2016. - Vyp. 1.- S. 477.

3. Konyshev E. V. Tipologiya turistsko-rekreacionnogo prostranstva // Geograficheskij vestnik. - Perm': Permskij gosudarstvennyj nacional'nyj issledovatel'skij universitet, 2020. - Vyp. 1(52).- S. 32.

4. Trunina M. Yu., Bilyk A. G., Chumakova I. M. Formirovanie rekreacionnogo prostranstva goroda: teoreticheskij aspekt // Turizm i gostepriimstvo. - Pinsk: Polesskij gosudarstvennyj universitet, 2020. -Vyp. 1. - S. 46.

5. Matyugina E. G. K voprosu formirovaniya rekreacionnogo prostranstva goroda // Ekonomika i predprinimatel'stvo. - Moskva, 2014. - Vyp. 4. - S. 201.

6. Bespalova A. A. Klyuchevye aktory konstruirovaniya rekreacionnogo prostranstva krupnogo rossijskogo goroda: potencial kreativnosti // Gumanitarij yuga Rossii. - Rostovna-Donu: Federal'nyj nauchno-issledovatel'skij sociologicheskij centr RAN, YUzhnyj federal'nyj universitet, 2016. - Vyp. 5. - S. 189.

7. Bespalova A. A. Kul'turno-istoricheskie faktory kreativizacii rekreacionnogo prostranstva krupnogo rossijskogo goroda // Gumanitarnye social'no-ekonomicheskie i obshchestvennye nauki. - Krasnodar: Nauka i obrazovanie, 2017. - Vyp. 10. - S. 17.

8. Baklazhenko E. V. Sovremennye tendencii mnogourovnevoj organizacii rekreacionnyh prostranstv $\mathrm{v}$ gorodskoj srede // Razvitie i aktual'nye voprosy sovremennoj nauki. Magnitogorsk: IP Vahrushev V.I., 2017. - Vyp. 7. - S. 172.

9. Mechkovskaya O. A. Teoretiko-metodologicheskie osnovy kompleksnogo ekonomikogeograficheskogo analiza turistskogo prostranstva // Social'no-ekonomicheskaya geografiya: istoriya, teoriya, metody: sbornik nauchnyh statej. - Smolensk: Universum, 2011. - $608 \mathrm{~s}$.

10. Vishnevskaya E. V. Razvitie sovremennogo gorodskogo prostranstva $\mathrm{v}$ turisticheskih celyah // Strategicheskie izmeneniya v sfere turizma i gostepriimstva: poisk novogo vektora razvitiya: materialy Vserossijskoj nauchno-prakticheskoj konferencii. - Moskva: Izdatel'stvo Rusajns, 2018. - S. 107.

11. Surzhikov V. I., Surkova A. S. Ocenka urovnya komfortnosti turistsko-rekreacionnyh prostranstv goroda // Territoriya novyh vozmozhnostej. Vestnik Vladivostokskogo gosudarstvennogo universiteta ekonomiki i servisa. - Vladivostok: Izdatel'stvo VGUES, 2020. - T. 12, vyp. 1. - S. 50.

12. Morozova V. V. Specifika rekreacionnogo prostranstva malogo istoricheskogo goroda na primere Rostova Yaroslavskogo // Yaroslavskij pedagogicheskij vestnik. - Yaroslavl': Yaroslavskij gosudarstvennyj pedagogicheskij universitet im. K. D. Ushinskogo, 2010. Vyp. 4. - C. 177. 
13. Slyunchenko R. A. Specifika rekreacionnogo prostranstva goroda Bryanska // Vestnik Bryanskogo universiteta. - Bryansk: Bryanskij gosudarstvennyj universitet imeni akademika I.G. Petrovskogo, 2014. - Vyp. 4. - S. 183.

14. Filanova T. V. Issledovanie gorodskih obshchestvennyh i rekreacionnyh prostranstv Samary // Tradicii i innovacii v stroitel'stve i arhitekture. Arhitektura i dizajn. - Samara: Samarskij gosudarstvennyj arhitekturno-stroitel'nyj institut, 2015. - S. 234.

15. Desyatnichenko D. Yu., Zaporozhan A. Ya., Kuklina E. A. Rekreacionnoe prostranstvo kak ob"ekt upravleniya innovacionnym razvitiem territorij goroda // Upravlencheskoe konsul'tirovanie. - Sankt-Peterburg: Rossijskaya akademiya narodnogo hozyajstva i gosudarstvennoj sluzhby pri Prezidente RF, 2017. - Vyp. 9. - S. 64.

16. SanPiN 2.1.7.3550-19. Sanitarno-epidemiologicheskie trebovaniya k soderzhaniyu territorij municipal'nyh obrazovanij: utv. Postanovleniem glavnogo gos. sanitarnogo vracha Rossijskoj Federacii ot 05.12.2019 № 20. Vvedeny s 26.12.2019 // Elektronnyj fond pravovyh i normativno-tekhnicheskih dokumentov. - URL: https://docs.cntd.ru/document/564067935?marker=6560IO (data obrashcheniya: 18.07.2021).

17. Svod pravil SP 42.13330.2016. «Gradostroitel'stvo. Planirovka i zastrojka gorodskih i sel'skih poselenij». Aktualizirovannaya redakciya SNiP 2.07.01-89: utv. Prikazom Ministerstva stroitel'stva i zhilishchno-kommunal'nogo hozyajstva Rossijskoj Federacii ot 30 dekabrya 2016 g. № 1034/pr. Data vvedeniya 01.07.2017 // Elektronnyj fond pravovyh i normativno-tekhnicheskih dokumentov. - URL: https://docs.cntd.ru/document/456054209 (data obrashcheniya: 20.07.2021).

() В.И. Суржиков, 2021

Для цитирования: Суржиков В. И. Организация событийных мероприятий в границах туристско-рекреационных пространств города // Территория новых возможностей. Вестник Владивостокского государственного университета экономики и сервиса. 2021. - T. 13, № 4. - C. 37-49.

For citation: Surzhikov V.I. Organization of events within the boundaries of tourist and recreational spaces of the city, The Territory of New Opportunities. The Herald of Vladivostok State University of Economics and Service, 2021, Vol. 13, № 4, pp. 37-49.

DOI https://doi.org/10.24866/VVSU/2073-3984/2021-4/037-049

Дата поступления: Одобрена после рецензирования: 16.08.2021
Одобрена п
05.10 .2021
Принята к публикации: 09.11.2021 